\title{
A Question of Power: Bessie Head and her Publishers
}

\section{CAROLINE DAVIS}

\section{OXFORD BROOKES UNIVERSITY}

\begin{abstract}
This article examines Bessie Head's turbulent relationships with her publishers and literary agents in London and New York, focusing on the publication of A Question of Power in 1973. It traces her business negotiations carried out from Serowe in Botswana and the difficulties she faced in getting the manuscript accepted, before it was eventually taken on by Heinemann Educational, Davis-Poynter and Pantheon Books. Based on new archival records, the article analyses the impact of the publishers' interventions in the text and paratexts of the novel, and it assesses her contracts with these publishers as well as her difficulties in obtaining royalties or remuneration. While her publishers and biographer have attributed her battles with the literary establishment to her volatile nature or to mental illness, this article draws attention instead to the difficulties that Head faced in forging a literary career.
\end{abstract}

Keywords: Bessie Head; Publishing; Women Writers; Print Culture; Editing; South Africa; Botswana; Literary Agents; Bourdieu.

\section{Introduction}

In December 1985, just four months before she died, Bessie Head wrote to her South African publisher, Ad Donker, 'I cannot stand writers and the writing world anymore', a statement that marked the end of a notoriously tempestuous literary career.1 Head's conflicts with her publishers and literary agents reached a crisis point during the publication of her third novel,

* I acknowledge gratefully the generous financial support I received from the British Academy and Oxford Brookes University School of Arts, which made this research possible. I would like to express my thanks to Dennis Walder and the anonymous readers of $J S A S$ for their constructive comments, and to David Johnson for helping me locate some important archival records. I also wish to thank the archivists at the National English Literary Museum in Grahamstown, the University of Reading Special Collections and Wits University Historical Papers for their invaluable help.

1 National English Literary Museum (hereafter NELM), 2007.12.1.12.24, B. Head, Serowe, to A. Donker, Johannesburg, 12 December 1985. 
A Question of Power, in 1973, and its immediate aftermath, which led to her dramatically severing her relationships with four publishers and two agents.

Several of her publishers and her biographer have written accounts of her publishing history, in which they have attributed these conflicts primarily to her difficult personal circumstances and her fragile mental health. For example, Randolph Vigne, her friend and the publisher of her early short stories in the New African, considered that her behaviour resulted from her tendency for 'great love, followed by the great let-down', and her sense of being geographically marginalised and cut off from her publishing centres: 'She developed fierce hatreds of those she did business with .... Much of this was because of her own remoteness and isolation'. 2 Patrick Cullinan - her one-time South African publisher friend and patron attributed these conflicts to her 'famously volatile' natures, while James Currey, her publisher in the African Writer's Series, viewed her stormy relationship with other editors and agents as a manifestation of schizophrenia.4 In a similar vein, Gillian Stead Eilersen, Head's biographer, argued that these disputes were illustrative of a long history of self-destructive professional and personal relationships: 'These outbursts of violent and irrational behaviour can of course be seen as symptoms of her unstable mental state'.5 This article reappraises Head's encounters with publishers and agents during the publication of Power, with reference to records and correspondence held in the National English Literary Museum in Grahamstown, Wits University Historical Papers, and the University of Reading. It considers whether these conflicts were simply 'symptoms of her unstable mental state', or whether they were a response to the specific difficulties she faced as a woman writer in Southern Africa.

2 R. Vigne, A Gesture of Belonging: Letters from Bessie Head, 1965-1979 (Portsmouth, NH, Heinemann Educational, 1991), pp. 191 and 210.

3 P. Cullinan, Imaginative Trespasser: Letters between Bessie Head and Patrick and Wendy Cullinan, 1963-1977 (Johannesburg, Wits University Press and Trenton NJ, Africa World Press, 2005), p. 258.

$4 \mathrm{~J}$. Currey, Africa Writes Back: The African Writers Series \& the Launch of African Literature (Oxford, James Currey, 2008), p. 221.

5 G. S. Eilersen, Bessie Head: Thunder behind her Ears (London, James Currey, 1995), p. 182. Additional accounts of Bessie Head's publishing history are James Currey's 'Publishing Bessie Head: Memories and Reflections' Wasafiri 46, 20 (2005), pp. 19-26; M. Lederer's 'Annotating Bessie Head's A Question of Power', Current Writing: Text and Reception in Southern Africa, 26, 2 (2014), and N. Leistikow's 'Marketing Bessie Head: Collection, Classification and the Negotiation of History' (MPhil thesis, Univerity of Oxford, 2001). 


\section{African Women Writers}

The dearth of published African women's writing in the second half of the $20^{\text {th }}$ century has been widely observed, but remains largely unexplained. Adeola James questions, for example, 'why there is no recognised female equivalent of Chinua Achebe, Wole Soyinka or Ngũgĩ wa Thiong'o', but draws no conclusions. 6 James Curry was unable to account for the gender imbalance in Heinemann's African Writers Series: 'In the early years, there are lamentably few books by women. This was not for want of looking'.7 Of the 143 titles published in the series before Head's A Question of Power in 1974, the only other works published by an African woman were Flora Nwapa's novels Efuru (1966) and $I d u$ (1970). Deborah Richey and Ellen Banda-Aku attribute the paucity of women writers in Africa to broad societal factors, including women's lack of privacy in the home, inequalities in both education and access to technology, and the lack of writing support.8 Ama Ata Aidoo blames it more specifically on gender bias amongst literary critics:

Now, as to the issue of where the female Achebes and so on are, you know that the assessment of a writer's work is in the hands of critics and it is the critics who put people on a pedestal or sweep them under the carpet, or put them in a cupboard, lock the door and throw the key away. I feel that, wittingly or unwittingly, people may be doing this to African women writers; literally locking us out, because either they don't care, or they actively hate us. Bessie Head died of neglect. So how is she going to be an Achebe? When nobody gives recognition to her as Bessie Head, as a woman in her own right trying to write ... something relevant and meaningful?'9

Aidoo's argument that women writers have suffered from critical neglect in comparison to male writers of the same calibre requires further investigation, and this article aims to assess

\footnotetext{
6 A. James, In Their Own Voices: African Women Writers Talk (London, James Currey, 1990), p. 3.

7 Currey, Africa Writes Back, p. 310.

8 D. Richey, 'Black African Women Writers: A Selective Guide' Collection Building, 14, 1 (1995), pp. 23-31, and E. Banda-Aaku, Journal of Southern African Studies, 40, 3 (2014), pp. 607-613.

9 A. James, 'Ama Ata Aidoo', In Their Own Voices, pp. 11-12.
} 
this largely untested hypothesis, that the literary establishment - and specifically the publishing industry - have relegated African women writers in general, and Head specifically, to a second-rate position.

\section{The Author-Publisher Relationship}

The author-publisher relationship has been envisaged using several metaphors, each of which conceptualises the gendered dynamics of this encounter in contrasting ways. An analogy long favoured by the publishing industry is that of the 'literary midwife', who offers a vital service to the author in bringing a work into existence; this dates from Geoffrey Faber's allusion to the publisher as a 'midwife of literature' in 192310 to Bodley Head editor Charlie Sheppard's description of his profession in 2015: 'We're like a strange breed of midwife who come and live with you and are often there at the conception, the delivery and through a lot of the nurture.' 11

Lewis Coser, by contrast, in his 1975 sociological investigation of publishing, designated the publisher a 'modern gatekeepers of ideas': one of the key 'institutional channels for the flow of ideas' with the power to 'make decisions as to what is let "in" and what is kept "out".' 12 Literary gatekeeping he defines as not only the decision to accept or reject a manuscript, but also the decision about how much to invest in a book's marketing and distribution: all factors that determine the fate of an author's work. The gatekeeper metaphor was revised by Lynne Spender in her 1983 analysis of patriarchy in the publishing industry. Focusing on the forgotten, unpublished heritage of women's writing, she identified the publisher as a prominent enforcer of gender exclusions: 'Publishers have acted as guardians of the gate and private, written words have required their approval in order to be transformed into public, printed words. Decisions in publishing are made by men and the processes involved in publishing are controlled by men', 13 and the publisher - the 'guardian of the gate' - is a literary censor, barring women writers from the public sphere.

10 G. Faber, A Publisher Speaking (London, Faber, 1934), p. 22.

11 'Top writing tips for new children's authors from top editors' 9 July 2015, The Guardian https://www.theguardian.com.

12 L. A. Coser, 'Publishers as Gatekeepers of Ideas', Annals of the American Academy of Political and Social Science, 421 (Sep 1975), pp. 14-22 at p. 15.

13 L. Spender, Intruders on the Rights of Men: Women's Unpublished Heritage (London, Pandora, 1983), p. 13. 
Pierre Bourdieu's more developed sociological model designates the publisher a 'merchant in art' or 'artistic mediator', 14 with the power to position writers in the literary field and determine their levels of 'symbolic capital'. 15 The publisher, according to his analysis, is one of the main 'producers of the meaning and value of the work' 16 who acts a judge of the spoken and unspoken rule of taste and value, the conditions of entry and progression, and designator of its differentiated forms of capital.17 In La Domination Masculine (1998), Bourdieu examines the mechanisms by which women are excluded from culture and society: how male domination operates as a representative form of 'symbolic violence', which he describes as 'a gentle violence, imperceptible and invisible even to its victims, exerted for the most part through the purely symbolic channels of communication and cognition (more precisely, misrecognition), recognition, or even feeling.' 18 He claims that the 'diminution of symbolic capital entailed by being a woman' is compounded by dark skin colour: 'Whatever their position in the social space, women have in common the fact that they are separated from men by a negative symbolic coefficient which, like skin colour for blacks, or any other sign of membership of a stigmatized group, negatively affects everything that they are and do ...'.19 Thus, femaleness and blackness are, in his analysis, 'negative symbolic' factors that lead to a diminished status and prestige in all aspects of society and culture. In addition to diminished symbolic capital, Bourdieu argues that reduced economic capital is a clear marker of male domination: 'The clearest indication of the uncertainties of the status granted to women in the labour market is no doubt the fact that they are always paid less than men, other things being equal'.20 Bourdieu's theory of masculine domination has been instrumental as a means of investigating gender inequalities in cultural institutions, for example in the

14 P. Bourdieu, The Rules of Art (Cambridge, Polity Press, 1996), p. 167 and The Field of Cultural Production (Cambridge, Polity, 1993), p. 11.

15 For a discussion of the relevance of Bourdieu in South African contexts, see Jared Zimbler, 'For Neither Love nor Money: the Place of Political Art in Pierre Bourdieu's Literary Field.' Textual Practice 23:4 (2009): 599-620 and Michael Burawoy and Karl von Holt Burawoy, Michael and Karl von Holt. Conversations with Bourdieu: The Johannesburg Moment. Johannesburg: Wits University Press, 2012. I discuss these debates further in C. Davis, 'Playing the Game: The Publication of Oswald Mtshali' in R. Dalleo (ed.), Bourdieu in Postcolonial Studies (Liverpool, Liverpool Univesity Press, 2016). ${ }_{16}$ P. Bourdieu, 'The Field of Cultural Production, or: The Economic World Reversed', in The Field of Cultural Production (Cambridge, Polity, 1993), p. 37.

17 P. Bourdieu, 'The Production of Belief', in Field of Cultural Production, pp. 74-111.

18 P. Bourdieu, La Domination Masculine (Paris, Seuil, 1998) and P. Bourdieu, Masculine

Domination Trans. Richard Nice (Stanford University Press, 2002), pp. 1-2.

19 Bourdieu, Masculine Domination, pp. 115 and 93.

20 Bourdieu, Masculine Domination, p. 92. 
work of Lois McNay and Kate Huppatz,21 while other scholars, notably L. McCall and Terry Lovell, have criticised his theory for its lack of agency or social change afforded to women, and because the concept of symbolic violence involves the complicity and collusion of those who are oppressed: the acceptance of the structures of inequality as 'natural' and legitimate by both dominant and dominated groups in society. 22

A key question then is whether any of these models of the publisher can usefully explain the racial and gender inequalities in literary institutions: in Bourdieu's terms, whether they can be utilised in the 'enterprise of unveiling' the 'established order with its relations of domination, its rights and prerogatives, privileges and injustices'23 I turn now to Bessie Head's early publishing career and chart the various stages in the publication of Power in an attempt to identify how these transnational literary power relations operated.

\section{Forging a literary career}

An author's 'social capital' is widely recognised as a vital factor in building a successful literary career. Bourdieu defines this form of capital as a 'network of connections' and contacts that people 'inherit or accumulate' (p. 301) and that provide individuals with power and advantages.24 In Toril Moi's words, it is the "relational power," that is to say the number of culturally, economically, or politically useful relations accumulated by a given person'.25 As a mixed-race woman writer living in Cape Town during the apartheid period, Head evidently felt herself to be lacking such 'relational power'. This is revealed in correspondence between Head and Langston Hughes in 1960, while she was living in Cape Town. She approached Hughes out of the blue, requesting financial assistance and advice about how to

21 K. Huppatz, Gender Capital at Work: Intersections of Femininity, Masculinity, Class and Occupation (Basingstoke, Palgrave Macmillan, 2012); Lois McNay, Gender and Agency: Reconfiguring the Subject in Feminist and Social Theory (Oxford, Wiley, 2000) and R. Massimo and K. M. Budd, 'Invisible Violence: Media (Re)Production of Gender Inequality in Italy, Communication Papers: Media Literacy and Gender Studies, 4, 7 (2015), pp. 11-12.

22 Bourdieu, Masculine Domination, p. 35. See critiques by L. McCall, 'Does Gender fit? Bourdieu, Feminism, and Conceptions of Social Order', Theory and Society, 21, 6 (December 1992), pp. 837-867 and Terry Lovell, 'Thinking Feminism with and against Bourdieu', Feminist Theory, 1, 1 (2000), pp. 11 - 32.

23 Bourdieu, Masculine Domination, p. 115 and p. vii.

24 P. Bourdieu, The State Mobility: Elite Schools in the Field of Power (Stanford CA, Stanford University Press, 1996), pp. 281 and 301.

25 T. Moi, 'Appropriating Bourdieu: Feminist theory and Pierre Bourdieu's Sociology of culture', New Literary History, 22, 4 (1991), 1017- 1049, at 1025. 
progress as an author: 'The difficulties overcome already have made many other Non-Whites say - "Let me get out of here". . . As you are aware, the type of oppression in S.A. creates an overwhelming sense of frustration.' 26 In a follow-up letter of December $12^{\text {th }} 1960$, she reported that she had sent a manuscript of short stories to Victor Gollancz in London. 'I have just given birth to a lot of baby ideas, shuffled them around in 16 short stories and packed them off to a publisher in England.... I had to start life this way, with a lot of babies. But they're sturdy!' 27 In reply, Hughes explained that he was not in a position to send her money, but he gave her advice for establishing a literary career:

I'm glad you're writing and have gotten some stories off to England. Good luck! If you could get an agent in London, it would save time and postage in case of rejections. Try and try again - which an agent can do with more facility. But sometimes getting a good agent is as hard as getting a publisher. Such are the trials and tribulations of writing.' 28

This correspondence between Head and Hughes gives an insight into the routes to book publication open to Head at a time when there were no black-owned book publishing houses in operation in South Africa and the white-owned liberal publishers - David Philip (1971), Ravan Press (1972) and Ad. Donker (1974) — were not yet established. A 'non-white' writer's only option was to approach an international publisher, which is what Head did in sending her unsolicited manuscript to Gollancz in London. As Langston Hughes predicted, the result was rejection: the publisher proved to be a somewhat deficient 'midwife' to Head's 'babies'. However, crucially for Head's career, she then followed Hughes's advice and agreed to her work being placed with a literary agency. As she explained to Hughes, 'Gollancz did not accept the collection of short stories, and they gave various nice reasons. They offered to place them with an agent and I said o.k.' 29 Soon afterwards, she established important relationships with literary agents, in particular with David Machin at A.P. Watts, thereby demonstrating an astute awareness of the importance of the agencies' social networks

26 NELM, 2011.84.2.8.1, B. Emery, Cape Town, to L. Hughes, New York, 10 October 1960. 27 NELM, 2011.84.2.8, B. Emery, Cape Town, to L. Hughes, $12^{\text {th }}$ December 1960. See D. Chioni Moore, 'The Bessie Head - Langston Hughes Correspondence, 1960-1961', Research in African Literatures 41, 3 (2010), p. 1 for further discussion of this correspondence.

28 L. Hughes to B. Emery, 3 January 1961, quoted in Moore 'The Bessie Head - Langston Hughes Correspondence' p. 13.

29 NELM, 2011.84.28.7, B. Emery, Cape Town, to L. Hughes, New York, 24 January 1961. 
as a means of negotiating with a literary world from which she was so geographically separated.

The publication of Head's first novels, When Rain Clouds Gather and Maru, was very positive and straightforward in comparison with her later experiences. As Gillian Eilersen recounts, Head was indebted to a female editor, Jean Highland at Simon and Schuster in New York, for her first break into publishing. Highland was so impressed with an article of Head's in the New Statesman that she wrote to her, asking if she had written a novel, and then arranging for her to be paid an advance of $\$ 80.30$ At this time, in 1966, Head lived in Botswana as an exile, and the resulting novel, When Rain Clouds Gather, was the tale of a young South African man who escaped apartheid to establish a new life in rural Botswana after decolonisation. Published by Simon and Schuster in 1968, it was an immediate success, both in terms of reviews and sales. When Jean Highland left for Bantam, she persuaded her new firm to publish the novel in paperback, and sent Head a sizeable $£ 1,000$ advance, with which she was able to build a new house. 31

The editor who replaced Highman at Simon and Schuster thereafter contacted Head to ask her to write a story for children in the Catcher in the Rye tradition. This is evidence of the tendency to categorise women writers as children's authors; but instead Head wrote Maru which she described as a 'masterpiece', though 'certainly not for little children'.32 The novel concerned a Masarwa - or 'Bushman' - teacher who comes to live in a Botswana village, where she is widely despised because of her race, but also becomes involved in a triangular love affair with the son of the village chief and his best friend. It was turned down by Simon \& Schuster, although this time Head had more success with Gollancz, who took it on as a UK hardback, while McCalls in New York published it in hardback for the US market. The UK paperback rights were sold to Penguin. UK educational rights went to Heinemann for their 'Windmill Series' and James Currey eventually managed also to obtain rights for the African Writers Series edition, publishing it in 1972.33 Thus Head achieved remarkable success with her first two novels, considering her lack of 'social capital' and her geographical distance from the literary capitals. Yet, despite having two novels published with prestigious hardback

30 Eilsersen, Bessie Head, p. 93

31 Eilersen, Bessie Head, p. 121.

32 Eilersen, Bessie Head, p. 134.

33 Archives of African Writers Series Archive, University of Reading Special Collections (hereafter URSC), HEB 13/3, J. Currey, London to B. Head, Serowe, 22 June 1972. 
firms in New York and London, paperback editions in both markets, good critical reviews and high sales, she had to prove her worth all over again with the publication of her third novel.

\section{Suppressing the Book}

From its inception to its publication, A Question of Power was a great struggle for Head. Described by her as 'almost autobiographical' 34 , she wrote the novel after experiencing a major psychotic episode in 1969, which led to several weeks of hospitalisation. The novel recounts the central protagonist Elizabeth's mounting crisis, her nightmares in a 'shared journey into hell' in the company of the hallucinated figures Dan and Sello, her mental breakdown and gradual, partial recovery, in the village of Motabeng in Botswana. In a letter to fellow writer James Matthews, she explained that she had to write the novel in order to explain her period of illness 'in the loony bin', and she described it as the tale of a long spiritual battle: 'The facts simply are that I do not fully know what I am fighting here except that it is evil. You will see from the book. It is a prolonged, hopeless battle.' 35 This internal conflict soon escalated into a major, public row when she attempted to get the book published.

Head experienced unanimous rejection when she sent her existing British publisher and agent the manuscript of Power in 1972. Giles Gordon, her editor at Gollancz, refused the manuscript on account of her 'misuse of the English language'. 36 She was particular shocked by his response, as her last book had been such a success: 'I could not grasp any hold on why he had really rejected the book. Giles brought out MARU which sold so well in England it went into a second printing.' 37 She then sent it to her London-based literary agent at A. P. Watt, Hilary Rubinstein, who had taken over her affairs after David Machin left. He replied that it was 'unprintable' and refused to send it on to her US Publisher, McCalls. 38 This enraged her, because her contract with McCalls specified that they would get first refusal on her third book. In Head's view, her agent and publisher were acting as gatekeepers and censors, as she declared in a letter to Randolph Vigne: 'Hilary Rubinstein has me tearing my

34 Eilersen, Bessie Head, p. 149

35 NELM 97.1.3, B. Head to J. Matthews, 4 October 1969.

36 URSC, HEB 13/3, B. Head to J. Currey, 16 June 1972.

37 URSC, HEB 13/3, B. Head to J. Currey, 16 June 1972.

38 URSC, HEB 13/3, B. Head to J. Curry 16 June 1972. 
hair out. He is rushing to suppress the book' 39. As a response, she wrote to Rubinstein, sacking him as her agent: 'Patronage galls me. I see that you are waiting patiently and hopefully for another book. Please do not bother. This letter is intended to end whatever business relationship we had.40 This counter-attack was a far cry from the 'self-denial, resignation and silence' 41 that Bourdieu regards as typical female responses to rejection and exclusion.

Head then experienced a further wave of rejections from her American publishers. She approached McCalls directly - by then taken over by Saturday Review Press - but they turned down the manuscript. Head reported that 'Saturday Review Press rejected it but it cost them sleepless nights and "agonising" as they said; They don't at all like the interior part of the book.' 42 In addition, Houghton Mifflin in America reviewed the typescript, but turned it down, stating that 'In its present state I do not believe the novel is successful as fiction'. 43 While outright rejection of a literary manuscript is commonplace for a first-time author, it is more surprising for an established author like Bessie Head, with a successful track record of sales and reviews. The symbolic capital Head had accumulated through the publication of her first novels had not led to an assured place in the British and American literary world.

\section{Publication and Prestige}

After suffering such extensive rejection by prestigious hardback literary publishers, Head tentatively approached James Currey to see if he might be interested in the manuscript for the paperback African Writers Series. She wrote, 'James, I am having awful trouble with my third book. It is called A QUESTION OF POWER. I need both a publisher, to read it sympathetically, and a new agent.' 44 He responded positively, but was baffled by how to categorise the book:

A Question of Power numbs me. I go back and back to it. We could publish it in African Writers Series though I don't think it is really African. It seems more

39 B. Head to R. Vigne, 4 June 1972, in Vigne, Gesture of Belonging, p. 162-163.

40 URSC, HEB 13/3, B. Head to H. Rubinstein, 16 June 1972.

41 Bourdieu, Masculine Domination, p. 49.

42 URSC, HEB 13/3, B. Head to J. Currey, 29 September 1972.

43 URSC, HEB 13/3, D. A. Ehrlich, Houghton Mifflin New York to R. Lister, 28 November 1972.

44 URSC, HEB 13/3, B. Head to J. Curry 16 June 1972. 
closely related to the main stream of Anglo-American internal writing, though the whole race thing gets across. ... It is big. You throw the lot on us and I really can feel, feel, feel though I cannot always understand. I know you have laid the inside of your head out on the paper.

Curiously, Currey considered the book not 'really African' because it failed to meet the usual conventions for social realism in African literature; it was 'internal'; it 'laid the inside of [her] head on the paper'. Yet, despite these reservations, he expressed his willingness to rescue the novel, and to publish it in the series: 'We are willing to give it exposure in African Writers Series as an experiment, seeing that it just does not seem to be considered right for the UK hardback/paperback market.' 45 Head was delighted with his 'rather wonderful' letter. She wrote: 'To say you like my book so much makes up for all the hysterical letters I have received so far'.46

In subsequent correspondence with Currey, Head mused on the fact that this novel marked a transition point in her writing career from the social realism of When Rain Clouds Gather and Maru to a more 'interior' realm. She wrote, 'I doubt very much that this book will get good reviews but if one follows the pattern of one's learning and life a stage has to come when one is no longer the 'critic's pet'. I have seen and have stacks of reviews to prove it.' 47 She reiterated this point in a letter to her copy-editor: 'If I had simply written a book about the project work in 'Motabeng village', it would have been snapped up on all sides, like my other books, with good reviews too." 48 She regarded Power as a significant shift in her writing career, away from accessible novels towards more experimental writing; in Bourdieu's terms, away from writing in the commercial pole of the literary field to writing at the 'autonomous' pole, based on symbolic profit.49 Currey recognised, however, that publishing an experimental literary novel within the African Writers Series was problematic; although he agreed to take a risk on Head's manuscript, he was candid that the book was unlikely to reach the UK or American literary marketplace, or to be widely reviewed, by this route. He explained, 'There is no better way to publish a book in Africa than in the African

45 URSC, HEB 13/3, J. Currey to B. Head, 24 August 1972.

46 URSC, HEB 13/3, B. Head to J. Currey, 31 August 1972.

47 URSC, HEB 13/3, B. Head to J. Currey, 20 November 1972.

48 B. Head to R. Lister, 19 November 1972, quoted in M. S. Lederer, 'Annotating Bessie Head's A Question of Power', Current Writing: Text and Reception in Southern Africa, 26, 2 (2014), pp. 162-168 at p. 166.

49 See Bourdieu, Rules of Art, p. 142. 
Writers Series. But if it is in that series, distribution in the UK will mainly be through African Studies channels.' 50 For, in the prestige economy of New York and London literary publishing, Simon and Schuster, McCalls and Gollancz were the most distinguished of the firms, the paperback trade publishers (like Penguin, Pan and Bantam) were further down the hierarchy, and least prestigious were publishers like Heinemann Educational, with their literature for the school market and African education market. In taking on Power, Currey acknowledged the mismatch between the novel and his paperback imprint. While his decision to publish Power saved it from oblivion, as he admitted, it was an uncertain triumph.

Currey was keen to find a hardback and paperback co-publisher for the novel, in order to secure a UK and US trade market; for example, he tried to persuade Caroline de Crespigny at Pan Books to take it on, without success. 51 Meanwhile, Head had somewhat surprisingly, given their previous ruction, decided to take on Giles Gordon as her literary agent after he left Gollancz to work for the Anthony Sheil agency. Gordon found a London-based hardback literary publisher, the small start-up firm Davis-Poynter, which agreed to take on the novel on condition that it would become the lead publisher, that all editorial and typesetting costs would be shared on an equal basis by both publishers, and that both publishers' advance and royalty payments would be paid to Head through Davis-Poynter. 52 Currey agreed to publish the overseas AWS edition at the same time as Davis-Poynter's hardback, but he would delay publication of the AWS UK paperback edition for one year. Head later expressed muted gratitude for Reg Davis-Poynter: 'He is the worst type of British person, austere, cold, dominating. But he bought A Question of Power and I've never got over being impressed by that gesture'.53 Gordon thereafter managed to secure Pantheon Books to publish the novel in hardback for the American market; this was Andre Schiffrin's radical left wing publishing imprint in New York which was a division of Random House, New York.

Thus, A Question of Power was eventually accepted by three publishers for three distinct markets, but, as Bourdieu argues, 'choosing the right place of publication' is 'vitally important because for each author, each form of production and product, there is a correspondingly natural site in the field of production, and producers and products that are

50 URSC, HEB 13/3, J. Currey to B. Head, 24 August 1972.

51 URSC, HEB 13/3, J. Currey to C. de Crespigny, 28 September 1972.

52 URSC, HEB 13/3, G. Gordon to J. Currey, 18 July 1972.

${ }_{53}$ Cullinan, Imaginative Trespasser, p. 188. 
not in their right place are more or less bound to fail'.54 While the eventual arrangement appeared to be satisfactory, the novel's rejection by the most 'consecrated' literary publishers had left Head with less prestigious firms and in a poor negotiating position; this was to have serious implications for the fate of the novel. 55

\section{Editing A Question of Power}

Head's three publishers unanimously agreed that Power required significant editing, and it was decided that Heinemann would carry out this work. Currey approached the matter with Head with some trepidation. In his first letter, he tentatively suggested that some re-writing was required to make the novel readable: 'The book will never be easy. But it could be made slightly more accessible. It is a public exposure of a very private thing.' 56 In response, she stated her willingness to revisit the manuscript, and expressed her desire for 'a buddy who can grab hold of the book and take it in stride'. 57 Currey recommended a freelance copyeditor, who might fit the bill: Richard Lister, who had recently worked on novels by the Sierra Leonean Pat Maddy, and by the South African Daniel Mdluli. According to Currey, Lister 'by some reorganisation and cutting and with practically no rewriting ... has provided work the authors have in fact not only accepted but have been positively enthusiastic about the result.' 58 Lister was extremely enthusiastic about the manuscript: 'I think it is a wonderful book. I feel very strongly opposed to the idea that the author should be asked to do any rewriting. The thing is superb as it stands ... It is a considerable achievement.' 59 He suggested some minor points of punctuation and phrasing that might be altered, and a few points of factual detail that he would like to clarify, but repeated that:

... any large-scale re-writing, either by the author or anybody else, is wholly unnecessary and undesirable. I found no difficulty myself in distinguishing between the subjective experiences and characters and the 'real' ones. This is not to say that the book is an easy read; it demands some effort of attention from the reader, and the effort is enormously rewarded. It is a considerable

\footnotetext{
54 Bourdieu, Field of Cultural Production, p. 95.

55 Bourdieu, Rules of Art, p. 124.

56 URSC, HEB 13/3, J. Currey to B. Head, 24 August 1972.

57 URSC, HEB 13/3, B. Head to J. Currey, $31^{\text {st }}$ August 1972.

58 URSC, HEB 13/3, J. Currey to B. Head, 21 September 1972.

59 URSC, HEB 13/3, R. Lister to J. Currey, 27 September 1972.
} 
achievement, a prolonged spiritual crisis seen from the inside and powerfully described. 60

Head wrote that this was 'the best encouragement I have had so far', and she agreed to work with him: 'I do look forward to Mr Lister's work on the book. I cannot help being grateful because I had just about given up on that book. I'll certainly co-operate with any questions he may have'.61 Thereafter, Lister and Head worked painstakingly on the manuscript. What Lister initially thought would be 'trifling editorial amendments' 62 turned out to be very detailed work on the manuscript, but he refrained from carrying out major re-structuring or re-writing. Head worked characteristically promptly and professionally on each set of corrections until they had a clean typescript. As Mary Lederer's study of the editing process confirms, Head approved every editorial change in the novel and no alterations were made without her consent.63 She was extremely grateful for Lister's attention to the novel, stating to James Currey, 'He treated the book so reverentially that I really adore him. He is quite a gift out of the blue sky because I had thoroughly despaired about "POWER".' 64 At Head's request, Lister continued with the book through the production stage, 65 and her verdict was that 'Richard Lister's editing is Superb!'.66 Production work was carried out by Heinemann, and the plates were sent to Davis-Poynter for their UK hardback edition, and to Pantheon for their US hardback edition. The editing process was therefore an example of a highly productive process, during which Currey and Lister played a hidden, but crucial, role in transforming a manuscript that had been deemed 'unreadable' into one that was both accessible and publishable. This also marked the beginning of Head's long-lasting literary relationship with Currey, who was to continue as her publisher until he left Heinemann in 1984.

\section{Marketing Bessie Head}

The cover of each edition of $A$ Question of Power was used as a prominent paratextual site for marketing both the novel and the author: the three distinct cover designs reflect the

\footnotetext{
60 URSC, HEB 13/3, R. Lister to J. Currey, 27 September 1972.

61 URSC, HEB 13/3, B. Head to J. Currey, 7 October 1972.

62 URSC, HEB 13/3, R. Lister to J. Currey, 27 September 1972.

63 Lederer, 'Annotating Bessie Head', pp. 166.

64 URSC, HEB 13/3, B. Head to J. Currey, 20 November 1972.

65 URSC, HEB 13/3, B. Head to J. Currey, 7 December 1972.

66 URSC, HEB 13/3, B. Head to J. Currey, 11 ${ }^{\text {th }}$ January 1973.
} 
publishers' attempts to reach a specific target market. The first edition, published by DavisPoynter in October 1973 at the standard hardback price of $£ 3.00$, was directed at the UK literary market. The understated jacket cover, that Gérard Genette would term almost 'mute', displayed only the book title and author's name in a black sans-serif and shaded typeface. 67 The blurb on the front jacket flap described the author as a 'born writer', and compared her with the established southern African author Doris Lessing. There is praise for this 'powerful and complex' novel, which is 'rich with irony, anger and passion, both emotional and intellectual'. On the back jacket flap, beneath a photograph of the author, is a story of Head's life as a stateless person living in exile in Botswana. The paratexts of this edition, emphasising the intellectual and philosophical worth of the book, aimed to position the book as a serious literary work and to promote the author as a natural genius; to create what John Thompson describes as a 'web of collective belief' in the new work, and thereby to encourage critical attention and reviews. 68 Head was satisfied with the proof version of the book, and wrote to Currey, 'Davis-Poynter have produced a very posh version of my book, and I could find few printer's errors'.69

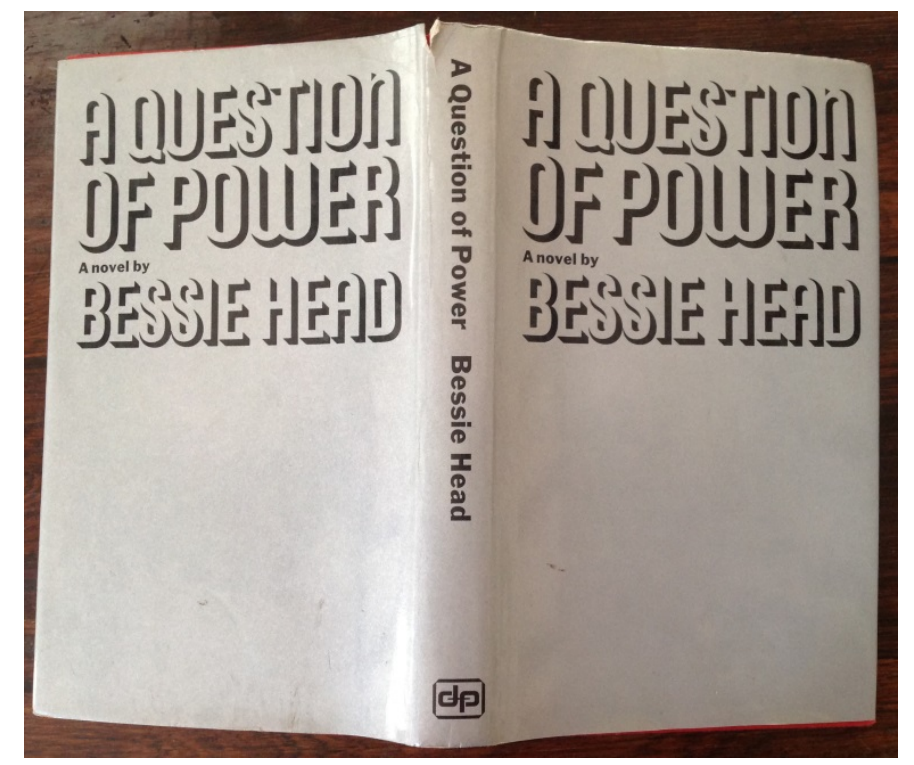

Figure 1: Bessie Head, A Question of Power (London, Davis-Poynter, 1973). Front and back cover.

67 G. Genette, Paratexts, p. 25.

68 J. Thompson, Merchants of Culture (Cambridge, Polity, 2010), p. 193.

69 URSC, HEB 13/3, B. Head to J. Currey, 11 July 1973. 
The Pantheon edition of the novel, published a year later in 1974 at a price of $\$ 6.95$, presented a striking contrast to the UK hardback edition, with its four-colour illustration on the front cover.70 The cover served primarily to position the book in a black female writing tradition: the racial identity of the protagonist is signified by the image of the African woman with acacia trees on the front cover. In addition, the image carries association of female madness, with an image superimposed on the woman's body that symbolises the character's inner conflict: the empty head shroud against a night sky is a crude representation of mental breakdown, and the sunlight breaking though clouds above, a conventional representation of optimism and hope. The back cover contains endorsements by Alice Walker and Nikki Giovanni, prominent Afro-American authors with the 'power to consecrate'. 71 They testify to the spiritual significance of the novel: Giovanni writes, 'Bessie Head, in A Question of Power, has detailed a journey to the depths of her being, confronting more realistically than The Exorcist the evil within us'. In a similar vein, Walker's review commends Head as 'one of the most important writers ... I find her vision trustworthy, her wisdom there to lean on, to borrow from, and to remember.' In addition, the blurb on the back jacket flap describes Head's life story, emphasising the parallels between the protagonist Elizabeth and the novelist, as a South African exile who had fled to Botswana, who has to report to the police each week, and who now works as a gardener in the village cooperative. The cover design thus promoted Head as a writer of universal truths and spiritual insights, although its overriding focus was on Head's race and personal life story. By these racialised and gendered paratexts, the novel was positioned in a niche position in the American literary hierarchy, within the sub-genre of black female writing.

70 This cover was designed by the Random-House book illustrator, Kurt Vargo. URSC, HEB 13/3, S. Herbert to A E Hoff, 22 August 1974.

71 Bourdieu, Field of Cultural Production, p. 75. 


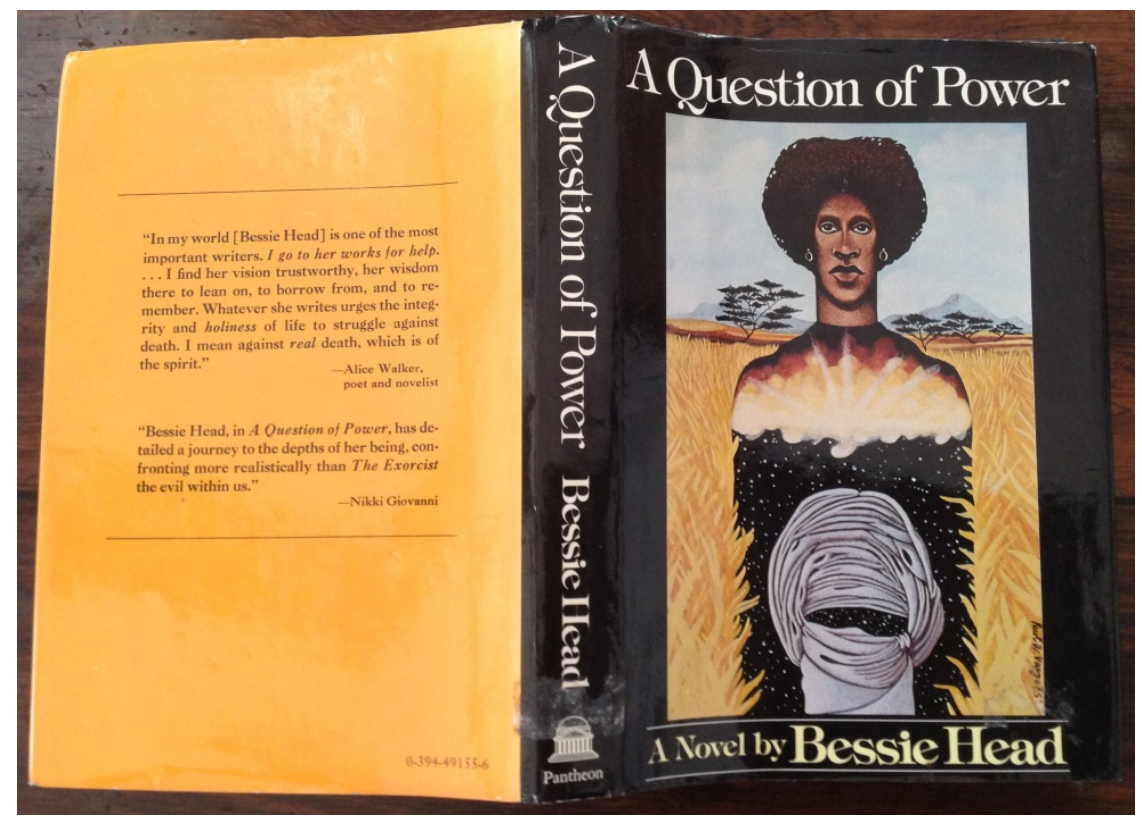

Figure 2: Bessie Head, A Question of Power (New York, Pantheon, 1973), Front and back cover.

The African Writers Series edition overtly promoted Power as a novel about African women and insanity. This paperback for the African market was published concurrently with the Davis-Poynter edition, and the UK paperback was released a year later on $29^{\text {th }}$ July 1974 , priced at $65 \mathrm{p}$. Evidently, the publisher realised the symbolic value and potential commercial value attached to the 'madness' label, for this is the defining feature of the book's paratext; it is signalled in the photograph of a huddled and naked black female on the front cover, and in the plot summary on the back cover that alludes to Elizabeth's 'mental breakdown', describing the novel as a 'mind-bending book which takes the reader in and out of sanity'. The back cover has a photograph of Head and a brief biography that draws attention to the close parallels between her life and that of her protagonist, thus creating associations of the mad, genius writer. This marketing strategy was calculated to attract maximum interest and sales, but it promoted an author persona and a reading of the novel that were neither sanctioned nor welcomed by Head. 


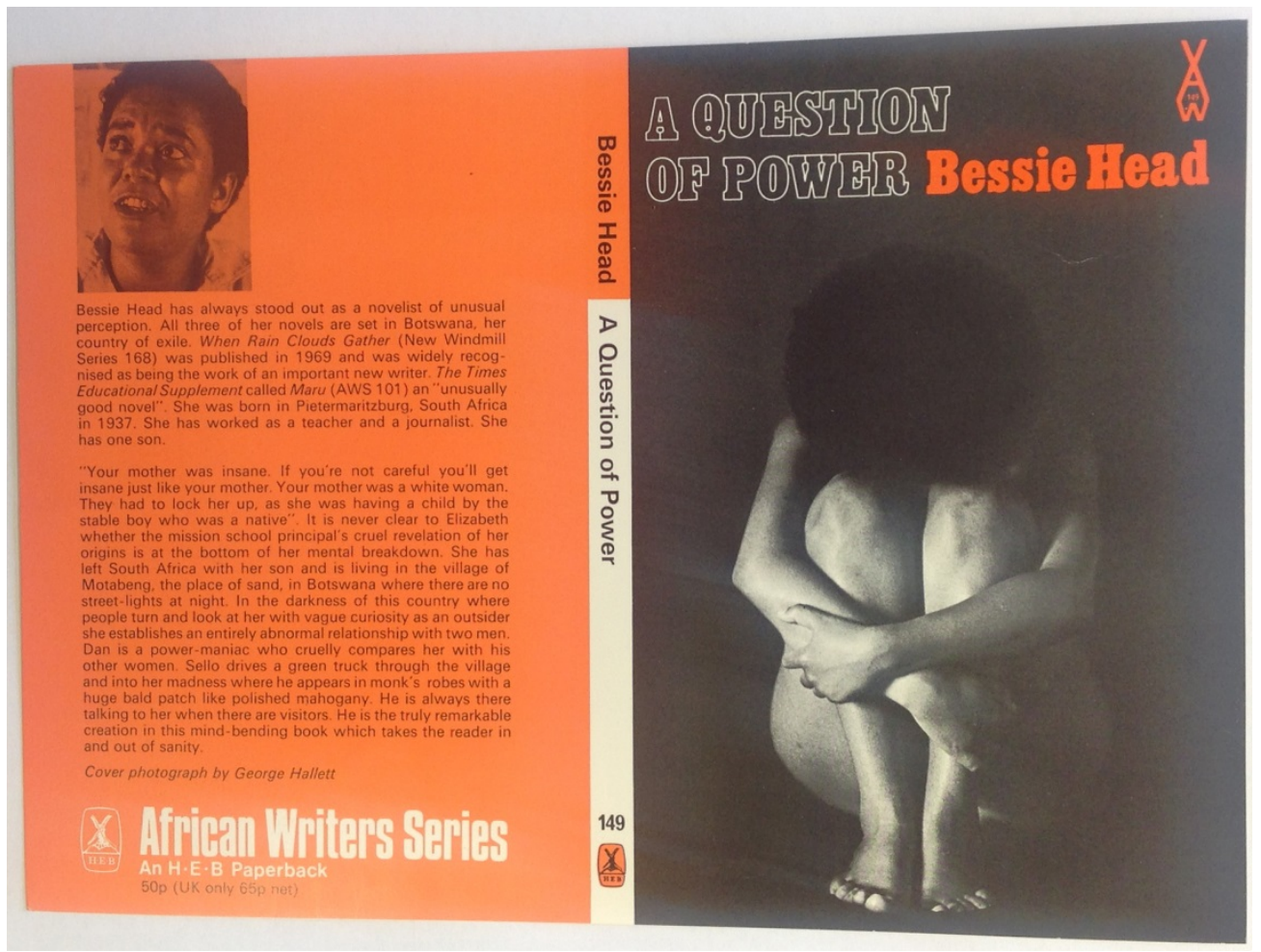

Figure 3: Bessie Head, A Question of Power (London, Heinemann, 1973). Front and back covers.

\section{Reception}

The critical reception of $A$ Question of Power was to prove a major disappointment for Head. In advance of publication, Davis-Poynter nominated Power for the 1973 Booker Prize, and she was full of optimism about her chances. To her friend Dotty Evans she wrote, 'The book has been entered for the 'Booker Prize' in England and the winner will be announced November $28^{\text {th }} \ldots$.. Davis-Poynter Ltd, my publishers, have praised the book to the skies. They like it immensely, so they say. ' 72 The Booker prize had been established only four years earlier and was already renowned for its substantial prize money. Head instantly planned what she would do with the $£ 5,000$ award.73 Yet much to her disappointment, the novel was not shortlisted and received no votes from the panel of three judges; the publisher's efforts to launch Power as an outstanding, award-winning work of literature were thwarted. 74

72 NELM, 92.2.6, B. Head to D. Evans, 4 August 1973.

73 NELM, 97.1.4, B. Head to J. Matthews, 6 November 1973.

74 Oxford Brookes University Booker Prize Archive, Shortlist 1973. 
Power was thereafter reviewed widely, although not always favourably. Like the blurbs on the book covers, the reviews were highly personal and biographical, identifying the chief interest of the book as the life of the author herself and her narration of the descent into madness. For example, a review by Russell Davies in The Observer described the novel as a 'brain scrambling experience', about a character 'on the borderline of a wretched schizophrenia'. He described her as a 'stateless' South African exile in Botswana who has had a 'hell of a time' as 'the product of that horror of horrors, a mixed and illicit union'. In his verdict, it is 'more the kind of book that will be saluted for its courage than for its accomplishment'. 75 Other reviews were more positive, but all emphasised the theme of African women and insanity. Ronald Blythe's judgement in The Sunday Times on $18^{\text {th }}$ August 1974 was that 'Bessie Head's vision of the separation of the mentally sick, and her ability to give mind-suffering a kind of picture language, convey a positively medieval horror' ${ }^{76}$ Charles Larson's review in Books Abroad of August 1974 praised its originality: 'Novels by African women are infrequent, psychological novels by African writers even more infrequent.', and he continues:

'The story, I suspect, is somewhat autobiographical ... the burden of exile mixed with guilt feelings about the color of her skin (she is coloured, not African) produce a kind of sexual frigidity, and for a time Elizabeth becomes mad.... In her concern with women and madness, Bessie Head has almost single-handedly brought about the inward turning of the African novel'.77

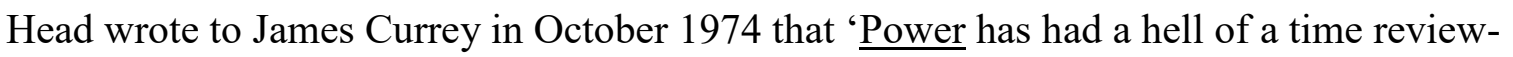
wise', 78 and in letters to James Matthews, she wrote of the 'harsh and mocking' reviews of the novel.79 Her only relief was that the American reviewers tended to read the novel as a book about universal spiritual themes rather than about 'women and madness'; she wrote to Matthews that 'all the English reviewers were offended by the book, and wrote deliberate lies about it. Surprisingly, the American reviews simply state what the book is about - it is about

75 R. Davis, 'Swallowing the Lexicon', The Observer, 9 December 1973, p. 36.

76 URSC, HEB 13/3, R. Blythe, 'A Question of Power by Bessie Head', Sunday Times, August 181974.

77 URSC, HEB 13/3. C. Larson, 'Bessie Head, A Question of Power', Books Abroad, August 1974 , p. 521.

78 URSC, HEB 13/3, B. Head to J. Currey, 2 October 1974.

79 NELM 97.1.7, B. Head to J. Matthews, undated. 
the soul. It is about questions of good \& evil.' 80 Head's dismay over the critical reception of Power, particularly in the UK, was then exacerbated further.

\section{'Learning about Capitalism the Hard Way'}

Head's greatest sense of grievance during the publication process occurred over her lack of income from Power, for she was entirely dependent on writing for a living. As a South African exile living in Botswana without a passport, and also as a single parent, she was unable to leave the country, and was cut off from sources of revenue that were open to many of her fellow South African writers, for example from teaching positions, American university scholarships or journal editorships.81 By means of a series of angry missives, Head entered into battles with her publishers and agents over her finances, which ultimately led to her terminating most of these relationships: only Heinemann was to survive the cull, although James Currey was not exempt from attack.

The first of these disputes was over the deduction of editorial costs from Head's advance against royalties. According to the contract, Heinemann was to pay a $£ 200$ advance to Head, half of which would be retained by Davis-Poynter and the remainder was for the author. But in fact, both publishers deducted editorial costs from the advance. Head wrote to Currey in May 1974, querying why she had failed to get the full sum: 'initially Giles G. said you were going to give me an advance of $£ 200$. Now, is that $£ 156.14$ the right advance or are you charging me up or anything like that, James? I hope you wouldn't do that to a poor, starving writer.' 82 Currey backtracked quickly, proposing to Davis-Poynter that they pay her the full amount: 'I had a rather painful cry from Bessie Head in the Kalahari about the deduction of editorial costs on the title... Might I suggest that we split the editorial fee of $£ 58.50$ and cost it into our own overheads and not against royalties?' 83 Davis-Poynter agreed to this arrangement, and Head received her full $£ 100$ advance from each publisher. 84

80 NELM, 97.1.5, B. Head to J. Matthews, 15 April 1974.

81 For example, Cam Themba and Zakes Mda were employed as school teachers, Oswald

Mtshai, Keorapetse Kgositsile, Lewis Nkosi and Wally Serote received scholarships to study in American universities, and Es'kia Mphahlele was editor of Black Orpheus and Director of the Congress for Cultural Freedom in Paris.

82 URSC, HEB 13/3, B. Head to J. Curry, 3 May 1974.

83 URSC, HEB 13/3, J. Currey to S. Herbert, 22 May 1974.

84 URSC, HEB 13/3, J. Curry to B. Head, 5 June 1974. 
A year after the publication of the book, Head queried why she had still not received any royalties from the book. She wrote to Currey, 'I am terribly poor. I walk around without a cent, 85 but she was informed by the finance department at Heinemann Education that she had not yet earned enough to pay off her advance. James Currey, anticipating her reaction, added a hand written note to the letter: 'Keep our fingers crossed. She may explode'.86 Sales of the book continued to be slow, and by December 1974, of the initial Heinemann 8,000 print run87, only 287 copies had been sold in the UK and 876 copies sold for export. 88 By 1975, Head reported that sales of the Pantheon edition were good, although she was still $\$ 30$ short of repaying her advance. 89 Head wrote of her financial difficulties in a letter to her friend in Grahamstown, Dot Ewan, in December 1974: 'Writing wise 1974 was a good year for me, but I failed to support myself financially although I wrote almost non-stop.' 90

The next incident was over her international taxation arrangements. It emerged in July 1975 that she had been losing approximately two thirds of her total earnings to taxation in Botswana, Britain and America, because there was no double taxation agreement between the countries. In July 1975, she explained to Pat Cullinan, 'the tax authorities decided to freeze my non-existent income in England. The publishers take $90 \%$ and the tax people want my $10 \%$. Perhaps I am learning about capitalism the hard way.' 91 Enraged, she threatened to withdraw all her work from publication in Britain and America:

At present I am ending my writing career... A little trickle of money comes through to keep your tongue hanging out. I see it badly because I had nothing at all but writing to live on. Now I'll start with nothing at all because I don't like donating typescripts to England and America for free. The publishers and the government take the lion's share. I get the donkey's share and eat grass. They fight like hell for the grass I'm living on. Well they can have it but not my work.... I know a writer is never missed and almost valueless.' 92

85 URSC, HEB 13/3, B. Head to J. Currey, 2 October 1974.

86 URSC, HEB 13/3, A. Hoff to B. Head, 27 October 1974.

87 URSC, HEB 13/3, Production Proposal, undated.

88 URSC, HEB 13/3, Royalty Statement, December 1974.

89 Cullinan, Imaginative Trespasser, p. 176.

90 NELM, 92.2.9, B. Head to D. Evans, 15 December 1974.

91 B. Head to P. Cullinan, 8 July 1975, quoted in Cullinan, Imaginative Trespasser, p. 229.

92 B. Head to P. Cullinan, 11 July 1975, quoted in Cullinan, Imaginative Trespasser, p. 230. 
This letter expresses Head's extreme frustration and sense that she was 'valueless' in the writing world, simply 'donating typescripts' for free. Her only weapon was to end her writing career. The threat was taken seriously, and Giles Gordon wrote to Currey,

... she has gone on record not only to people in this country but to the President of Botswana saying that if her tax situation isn't resolved in such a way that she loses substantially less of her income she will almost definitely write no more for publication in Britain or America. With most people one would probably dismiss this as an idle threat. Those of us who know or have dealt with Bessie over the years absolutely accept that it's a threat she would most likely carry out.93

Although Head eventually managed to sort out the double taxation situation, she sacked Gordon as her agent in October 1975 on account of the 'complete chaos' that he had made of these arrangements. 94

Her argument with Davis-Poynter intensified the following year, when she had still received no royalties at all from the firm. She wrote to Randolph Vigne in May 1976 expressing frustration that Reg Davis-Poynter was not replying to her letters, evidently 'as punishment for not being a money spinner'. By this stage, only 796 copies of the hardback edition had been sold, which meant that her royalties were still insufficient to cover her advance. As set out in the original contract, Bessie Head's royalty payments from Heinemann were channelled through Davis-Poynter, and the firm was waiting until it had recouped the $£ 100$ advance that it had paid to Head, before sending the royalties on to her. She was outraged by this arrangement, perceiving it a great injustice that she, struggling to survive in her village in Botswana, was earning an income for her London publisher. She wrote in desperation to Vigne, 'I have no resources at all to live on and am at the end of my tether.... I am not going to earn any money for a hardcover publisher in England.' 95 In a further letter to Cullinan, Head described herself as a pawn in a game in which the odds were stacked against her: 'I

93 URSC, HEB 13/04, G. Gordon to J. Currey, 8 September 1975.

94 B. Head to P. Cullinan, 29 October 1975, in Cullinan, Imaginative Trespasser, p. 237. 95 Vigne, Gesture of Belonging, p. 202-3. 
could not get anything straight with the Davis-Poynter man. He's got a game going and I can't see all the cards. I am fucking sick of it.' 96

At this time, Head was involved in complicated and prolonged negotiations over the publication of her next books, Serowe and Collector of Treasures, with Davis-Poynter, Pantheon, Heinemann and Patrick Cullinan's Bateleur books in Johannesburg. This led to a permanent breach with Pantheon Books in February 1975,97 and in the following year with Cullinan and Bateleur.98 In June 1976, Head's fraught relationship with Davis-Poynter was finally terminated, as recounted by Reg Davis-Poynter in a letter to James Currey: 'I am sorry to tell you that Bessie Head has decided that I am a crook, so that with great regret I have written to her to say that I can no longer be associated with her in any way. I don't want to go into the lunatic details in a letter.' 99 James Currey responded:

'I certainly don't want to hear the lunatic details. It is too painful to see a person shooting down people on impulse. I will now step forward into the firing line expecting a bullet to the heart. A UCH [University College Hospital] psychiatrist friend described A Question of Power as an essential piece of reading for his students when they are studying schizophrenia' 100

Head's publishers regarded her behaviour as 'lunatic' and a manifestation of schizophrenia, and her biographer apportioned the blame for these conflicts directly onto Head herself: 'Relentlessly, brick by brick, Bessie had been pulling down the framework for all her creative expression. Now the whole structure was crashing round her ears. Though she did not see it like that, there was no one to blame but herself.101 Yet, attributing Head's behaviour to psychological factors alone fails to take into account the severity of her financial situation at

96 B. Head to P. Cullinan, 31 May 1976, in Cullinan, Imaginative Trespasser, p. 249. For exposition of Bourdieu's theory of the game, see Rules of Art, p.228 and Masculine Domination, p. 49. 97 See Cullinan, Imaginative Trespasser, pp. 183-197.

98 See Cullinan, Imaginative Trespasser, pp. 250-259. Note that $A$ Collector of Treasures and

Serowe: Village of the Rainwind were published by Heinemann in paperback and David

Philips in hardback for the South African market, in 1977 and 1981 respectively. 99 URSC, HEB 13/04, R. G. Davis-Poynter to J. Currey, 9 June 1976, RA) 100 URSC, HEB 13/04, James Currey to R. G. Davis-Poynter, 15 June 1976. 101 Eilersen, Bessie Head, p. 181. 
this stage; three years after the publication of Power, she had still received no royalties from her British publishers, and she was evidently living in a state of extreme poverty. 102

Head's financial grievances with publishers and agents were to continue until the last months of her life. As late as 1983 she reported in a letter to Jane Bryce, a lecturer in African literature, that she had still failed to receive any royalties from Davis-Poynter, and claimed that 'Davis-Poynter Ltd stole book royalties on the Heinemann AWS edition of A Question of Power for nine years. Giles Gordon sorted this out but was unable to recover the stolen money.' 103 It was only in 1983, when Davis-Poynter sold his business, that she was able to set up a new contract with Heinemann African Writers Series that cut out Davis-Poynter. 104 In addition, from 1981-1985 Head had a long-standing conflict with the literary agency, A. P. Watt, over what she termed the 'theft of my book royalties' 105. She claimed the firm had failed to pass on to her the advance and royalties that had been paid to her by the Dutch publisher Novib for their translation of When Rain Clouds Gather. Eventually, in 1985 she reported that Novib had sent her the missing royalty payments and that they had taken up legal action against A. P. Watts to reclaim the money.106 Her sense of disillusion with the literary industry was expressed in a letter to Jane Bryce: 'I went into a state of catatonic shock when I saw that agents, publishers and university people would steal from me. The state of extreme shock was caused by my extreme aloneness. I only have myself and my son.' 107

\section{Conclusion}

102 See Cullinan, Imaginative Trespasser, p. 176. Later, in a letter to Hilda Bernstein, she described herself as 'desperately poor' and living 'from hand to mouth with a constant worry about survival'. University of Witwatersrand Historical Papers (hereafter UWHP), B. Head to H. Bernstein, 24 November 1981.

103 NELM 2006.5.3, B. Head to J. Bryce, 21 June 1983. See also reference to this in NELM 2006.5.5, B. Head to J. Poynter of 17 February 1984: 'Davis-Poynter stole these royalties for nine years but he stole from other writers as well because he had to flee London.'

104 NELM 2006.5.5, B. Head to J. Bryce, 17 February 1984, p. 2.

105 Head to Bernstein, $9^{\text {th }}$ October 1985

106 UWHP, B. Head to H. Bernstein, 9 August 1985. This is also discussed in NELM 2006.5.3, B. Head to J. Bryce, 21 June 1983.

107 NELM 2006.5.4, B. Head to J. Bryce, 27 July 1983. Head's conflicts with academics from the University of the Witswatersrand for their failure to remunerate her for the time she had given to lecturers and students are recounted by Eilersen, Bessie Head, pp. 255 and 273-4. 
A Question of Power went on to become one of Bessie Head's most acclaimed novels. In 1981 it was ranked by the journal Black Scholar as the eighth of fifteen 'most influential books for the decade', 108 and it was listed as one of Africa's 100 Best Books in 2002. It was translated into French and Spanish and went into several new paperback editions, including within the Penguin Modern Classics series in 1991, as a Longman edition for the US market, and in the newly established Penguin African Writers series in October 2011. The book continues to sell well in the Heinemann African Writers' Series, now owned by Pearson.109 However, for Head the process of publication was one of frustration and disappointments, which persisted until her death. As Craig McKenzie writes, 'it was also from the time of its appearance the source of Head's greatest anxiety regarding her own life and literary worth as a writer, and she was to return compulsively to its defence throughout the remainder of her life.' 110

Bessie Head had dramatically different experiences of publishers and agents during the publication of Power. Initially, she deemed them suppressors of the novel - 'gatekeepers' but she later regarded her Heinemann editors as vital supporters of her work, even 'midwives'. However, Bourdieu's designation of publishers as 'merchants in art' comes closer to conveying the subtle ways in which she and her work were positioned in the literary and economic hierarchy. That she was ultimately consigned to a subordinate position is demonstrated by the rejection of the novel by the most prestigious publishers in London and New York, which left her in a weaker negotiating position with lower-status imprints. It was also evident in the way that her life story obscured the work itself, both in terms of the marketing of the novel and its critical reception. Yet, her diminished power and influence were most apparent in her persistent difficulties in securing royalty payments from the novel. The conflicts that took place between Bessie Head and her publishers - previously dismissed as symptomatic of her 'volatile nature' and her mental illness - provide an insight into the hidden power structures and endemic inequalities in the Anglo-American 'writing world'.

CAROLINE DAVIS

108 C. McKenzie, 'Randolph Vigne, A Gesture of Belonging', Journal of Southern African Studies, 19, 2 (June 1993), p. 348.

109 In the period 2000-2016, 787 copies of the African Writers Series edition sold. In the same period, the book sold only 222 copies as a Penguin Modern Classic (now out of print) and only 42 in its most recent edition in the Penguin African Writers series. 'Nielsen BookScan search carried out on 1 March 2017, http://online.nielsenbookscan.net.

110 C. McKenzie, 'Randolph Vigne', p. 348. 
School of Arts

Headington Hill Hall

Oxford Brookes University

Oxford

OX3 OBT

cdavis@brookes.ac.uk 